\title{
Daily Changes in GT1-7 Cell Sensitivity to GnRH Secretagogues That Trigger Ovulation
}

\author{
Sheng Zhao Lance J. Kriegsfeld \\ Department of Psychology, and Helen Wills Neuroscience Institute, University of California, Berkeley, Calif., USA
}

\author{
Key Words \\ Gonadotropin-releasing hormone $\cdot$ Kisspeptin $\cdot$ Vasoactive \\ intestinal polypeptide $\cdot$ Reproduction
}

cells are capable of intrinsic circadian cycles that may be fundamental for coordinating daily changes in sensitivity to signals impacting the reproductive axis.

Copyright $\odot 2009$ S. Karger AG, Basel

\section{Introduction}

Optimal brain and body functioning and the maintenance of homeostasis require the precise temporal coordination of numerous hormonal systems [1]. On a daily schedule, these rhythms are controlled by an endogenous circadian timing system that includes both a central, master clock in the suprachiasmatic nucleus (SCN) $[2,3]$ and subordinate clocks throughout the central nervous system and periphery [4]. In mammals, there are at least two major routes by which the SCN coordinates rhythmic function: hormonal communication [5-8] and autonomic nervous system outputs [9-13]. To achieve systemspecific regulatory flexibility, at least some of the downstream signals modulated by the circadian clock vary according to local needs [14].

At the cellular level, circadian oscillations are controlled by a number of autoregulatory transcription-translation feedback loops $[15,16]$. The core feedback loop is driven by Clock: Brain and muscle aryl hydrocarbon receptor nuclear translocator (ARNT)-like-1 (BMAL-1)-mediated transcription of three Period (Per) gene orthologs and

\section{KARGER}

Fax +4161306 1234

E-Mail karger@karger.ch

www.karger.com (c) 2009 S. Karger AG, Basel

Accessible online at:

www.karger.com/nen
Lance J. Kriegsfeld, Neurobiology Laboratory

Department of Psychology and Helen Wills Neuroscience Institute

University of California, 3210 Tolman Hall, \#1650

Berkeley, CA 94720-1650 (USA)

Tel. +1 510642 5148, Fax +1 510642 5293, E-Mail kriegsfeld@berkeley.edu 
two Cryptochrome (Cry) gene homologs. Rhythmic expression of these genes is not only seen in the SCN, but also throughout the central nervous system and periphery, although the coherence of these peripheral oscillators requires a functional master clock $[17,18]$. Importantly for the present work, core clock genes and clock-controlled genes are expressed in neurosecretory cells, including GnRH neurons $[19,20]$, the pituitary gland $[21,22]$ and a number of peripheral endocrine glands [2, 23, 24], implying a potential intrinsic mechanism of temporal gating which controls hormone secretion.

Given the ability of hormones to have widespread impact throughout the body via the circulatory system, it is important to gain an understanding of circadian endocrine regulation. Daily patterns of hormone secretion are controlled by direct synaptic connections from the SCN to neurosecretory cells in the brain [1]. The SCN also projects multisynaptically to endocrine glands via the autonomic nervous system, although the function of this means of communication remains unspecified [25-28]. For vertebrate reproduction, the precise timing of the hypothalamo-pituitary-gonadal (HPG) axis is crucial [2931], and direct SCN projections to GnRH neurons have been identified across species [19, 32-34].

In some female rodents, a neural signal arising from the SCN triggers GnRH secretion and induces the preovulatory LH surge on the afternoon of proestrus [35]. Lesioning the SCN or blocking neural output from the SCN eliminates the LH surge [36, 37]. Direct projections from SCN vasoactive intestinal polypeptide (VIP)-expressing cells to GnRH neurons are thought to be critical in LH surge generation [32, 33, 38]. VIP-2 receptors have been found in a subset of GnRH neurons in vivo [39] as well as in the GnRH-releasing cell line, GT1-7 cells [40], further suggesting direct effects of VIP on GnRH neurons. Importantly, manipulations of VIP both in vitro $[40,41]$ and in vivo lead to marked changes in GnRH and gonadotropin release [34, 42, 43].

In addition to direct $\mathrm{SCN}$ regulation of the GnRH system, the SCN projects extensively to the anteroventral periventricular nucleus (AVPV), a brain region associated with the induction of the preovulatory LH surge [44-48]. Kisspeptin, a product of the anti-metastatic KiSS-1 gene [49] and a potent stimulator of the HPG axis, is highly expressed in the AVPV and has been implicated in the initiation of the LH surge [50]. These findings suggest that kisspeptin may act as an intermediary between the SCN and the reproductive axis as an additional mechanism of ovulatory control. Kisspeptin is believed to communicate directly with the GnRH system via G-protein-coupled re- ceptor 54 (GPR54) [49, 51, 52]. A large proportion of GnRH cells co-express GPR54 mRNA in rodents, further pointing to direct actions of kisspeptin on the GnRH system [53-55]. In accord with these findings, direct kisspeptin application depolarizes GnRH neurons [53]. Finally, gonadotropin release triggered by kisspeptin can be blocked by $\mathrm{GnRH}$ antagonists [51, 54, 56], suggesting that kisspeptin does not act at the level of the pituitary.

Because the LH surge occurs during a limited time window and GnRH cells express circadian clock 'machinery', we investigated the possibility that the GnRH system exhibits circadian changes in sensitivity to peptides stimulating $\mathrm{GnRH}$ release. Such a mechanism would allow local control of ovulatory function at the level of the GnRH system. We examined the response to peptides putatively involved in direct (VIP) and indirect (kisspeptin) circadian actions on the GnRH system. One possibility is that GnRH cells respond differentially across the circadian cycle to both VIP and kisspeptin. This outcome would suggest that the initiation of the surge depends, at least in part, on the timing of responsiveness to direct and indirect SCN signals. Alternatively, it is possible that GnRH cells respond equally throughout the circadian cycle to stimulation, suggesting that the timing of ovulation is controlled by the timed secretion of these peptides by the circadian system. Finally, the GnRH system may respond in a circadian fashion to one of these peptides but not the other, suggesting a combination of these two mechanisms in initiation of the LH surge.

\section{Materials and Methods}

\section{Cell Culture}

Nucleotide primers and cell culture reagents were obtained from Invitrogen (Carlsbad, Calif., USA). All other reagents were purchased from Sigma-Aldrich (St. Louis, Mo., USA) if not otherwise specified. GT1-7 cells were cultured in 100-mm master plate in Dulbecco's Modified Eagle's Medium (DMEM, CA No. 11995-065) and supplemented with $10 \% \mathrm{FBS}, 100 \mathrm{U} / \mathrm{ml}$ penicillin, and $100 \mu \mathrm{g} / \mathrm{ml}$ streptomycin in a humidified atmosphere of $5 \%$ $\mathrm{CO}_{2}$ at $37^{\circ} \mathrm{C}$. Media was replaced every $2-3$ days until confluence was reached. For experiments, the cells utilized were of similar passage (passage 13-20) and confluence ( 90\%).

\section{Serum Shock and Peptide Treatments}

For the serum-shock treatment, regular culture media was replaced by DMEM supplemented with 50\% FBS. Two hours after serum shock, cells were switched into serum-free (SF) DMEM [57, 58]. At indicated time points, cells were re-balanced in fresh SF DMEM for 30 min before kisspeptin and VIP treatment to remove the accumulated GnRH resulting from baseline release. Each peptide was then added to experimental wells and incubated for $45 \mathrm{~min}$. As a result, each time point represents a collection of in- 
dividual samples stimulated, only once, at various time intervals after the initial serum shock, not a within-subject design with the same cells being stimulated, or samples collected repeatedly. At each time point, the treated individual samples were compared with untreated control wells that were collected for real-time PCR $(n=3)$ or fixed for quantification using a cellular ELISA $(n=4)$.

\section{Reverse Transcription PCR}

Reverse transcription PCR (RT-PCR) was performed on mouse brain and GT1-7 cells. Tissue and cells were collected and their total RNA were extracted (RNeasy Mini Kit; Qiagen Inc., Valencia, Calif., USA). 3'-RACE cDNA was then synthesized (SMART cDNA synthesis kit; Clontech Laboratories Inc., Palo Alto, Calif., USA). Touchdown PCR was then conducted using specific primers (sense: 5'-CGTTA TCTGC CGCCA CAAGC-3', and antisense: 5'-TTGCT GTAGG ACATG CAGTG AGCC-3') for mouse GPR54: 3 min $95^{\circ} \mathrm{C}$ initial denaturing followed by 16 touchdown cycles from 68 to $60^{\circ} \mathrm{C}$ (annealing temperature, decrease $0.5^{\circ} \mathrm{C}$ every cycle) and continued for another 25 cycles with $60^{\circ} \mathrm{C}$ annealing temperature.

\section{mRNA Quantification}

Cells stimulated at each time point and their relevant untreated controls were harvested and total mRNA was purified. Total RNA was extracted by using the Absolutely RNA Microprep Kit (Stratagene, La Jolla, Calif., USA). $0.5 \mu \mathrm{g}$ total RNA was reverse transcribed to cDNA using the iScript cDNA Synthesis Kit (BioRad Laboratories, Hercules, Calif., USA). Real-time PCR was then performed as previously described [59]. Briefly, $0.5 \mathrm{ng} / \mu \mathrm{l} \mathrm{cDNA}$ (RNA equivalent) for each sample was used as a template for quantitative PCR using the IQ5 Real-Time PCR Detection System (Bio-Rad Laboratories). PCR parameters were: $5 \mathrm{~min}$ at $95^{\circ} \mathrm{C}, 45$ cycles of $30 \mathrm{~s}$ at $95^{\circ} \mathrm{C}, 30 \mathrm{~s}$ at $60^{\circ} \mathrm{C}$, and $30 \mathrm{~s}$ at $72^{\circ} \mathrm{C}$, followed by melt curve analysis. The raw fluorescent data were analyzed by the Real-time PCR Miner program [59]. The resulting PCR efficiency and fractional cycle number at the threshold (CT) were used for gene quantification. $\beta$-Actin was used as an internal control to normalize mRNA levels among samples. The following primers were used for $B M A L-1$ : 5'-GCACC AGTGG TGTGG ACTGC AA-3' (sense), 5'-TGCAT ATTCT AACCT TCCAT GAGGG TC-A-3' (antisense); Period-2: 5'-ACGGG ACTCT CAGGG CAGTG ACTG-3' (sense), 5'-GTTCT TTGTG TGCGT CAGCT TTG-3' (antisense); GnRH-1: 5'-CCAGC CAGCA CTGGTCCTAT GG-3' (sense), $5^{\prime}$-CCAGA GCTCCTCGCA GATCC CT-3' (antisense); and $\beta$-Actin: $5^{\prime}$-CAGGG TGTGA TGGTG GGAAT GGG-3' (sense), 5'-CCTCG GTGAG CAGCA CAGGG T-3' (antisense).

\section{Enzyme-Linked Immunosorbent Assay}

A cellular ELISA was performed for GnRH using $\beta$-actin as an internal control. Peptide-treated wells and time-paired controls were used for each time point. Briefly, cells in individual wells were fixed in $4 \%$ paraformaldehyde in PBS followed by washes $(3 \times)$ in $\mathrm{dH}_{2} \mathrm{O}$. PBS with $0.6 \%$ hydrogen peroxide $\left(\mathrm{H}_{2} \mathrm{O}_{2}\right)$ was then added for $20 \mathrm{~min}$ at room temperature (RT) to quench endogenous peroxidase activity. After one wash in PBS, wells were treated with blocking buffer (2\% BSA in PBS with $0.1 \%$ Triton $\mathrm{X}-100)$ for $30 \mathrm{~min}$. Cells were then incubated with the primary antibody solution (rabbit anti-GnRH (CA No. 20075; ImmunoStar, Hudson, Wisc., USA) and mouse anti- $\beta$-actin (CA No.
JLA20; Developmental Studies Hybridoma Bank, Iowa City, Iowa, USA), 1:2,000 diluted in blocking buffer with $0.1 \%$ Triton X-100 for $2 \mathrm{~h}$ at RT followed by 5 washes in PBS. Biotin-conjugated antirabbit secondary antibody solution (1:1,000 in blocking buffer with $0.1 \%$ Triton $\mathrm{X}-100$ ) was then added to wells and incubated for $2 \mathrm{~h}$ at RT followed by 5 washes in PBS. Cells were then incubated with streptavidin-conjugated HRP solution $(1: 1,000$ in blocking buffer) for $2 \mathrm{~h}$ at RT followed by 5 washes in PBS. SureBlue TMB 1-Component Microwell Peroxidase Substrate (Ca No. 52-00-01; KPL, Gaithersburg, Md., USA) was then added and cells were incubated at RT until the reaction was terminated by the addition of $1 \mathrm{~N}$ hydrochloric acid $(\mathrm{HCl})$. Resulting $\mathrm{OD}$ values were read at $450 \mathrm{~nm}$ using a plate reader (Biorad) within $\sim 30 \mathrm{~min}$. The ELISA for released GnRH-1 was performed using a luteinizing hormone-releasing hormone (LHRH) EIA kit (Bachem, Torrance, Calif., USA). All procedures recommended by the manufacturer were followed precisely and the standard curve $(0.0064$, $0.032,0.16,0.8,4.0$, and $20 \mathrm{ng} / \mathrm{ml}$ ) was parallel to a serially diluted sample, further validating the assay.

\section{Statistics}

Data were analyzed by SPSS software using a one-way analysis of variance (ANOVA) to assess main effects of time-course and peptide treatment. To examine significant differences between individual time points and the daily nadir of expression, twotailed Student's t tests were used. For the kisspeptin dose-response curve, two-tailed Student's t tests were performed between treated wells and control samples. Results were considered statistically significant when $\mathrm{p}<0.05$.

\section{Results}

\section{Clock Genes and GnRH Expression Are Rhythmic in GT1-7 Cells}

To confirm the existence of an intrinsic rhythm in clock gene expression in GT1-7 cells, real-time PCR was performed to quantify Period-2 and BMAL-1 mRNA across the circadian cycle ( $\mathrm{n}=3 /$ time point/gene). Both genes exhibited a daily pattern of expression with peaks consistent with a 24 -hour rhythm ( $\mathrm{p}<0.05$ in each case). As expected, these two rhythms were in anti-phase (i.e., $\sim 12$ h out of phase), consistent with the well-established clock regulation model, and further corroborating the measurement of this pattern of expression [60-62]. During the 46-hour monitoring period after serum shock, $B M A L-1$ mRNA was at a trough from 13 to $16 \mathrm{~h}$, and recovered between 25 and $37 \mathrm{~h}$, while the mRNA of Period2 exhibited the opposite pattern (fig. 1).

\section{Dose-Dependent Stimulation of GnRH Release by \\ Kisspeptin in GT1-7 Cells}

By using RT-PCR, we found two alternatively spliced isoforms of GPR54 expressed in GT1-7 cells (fig. 2; GenBank No. EU532437 and EU879091). To examine wheth- 


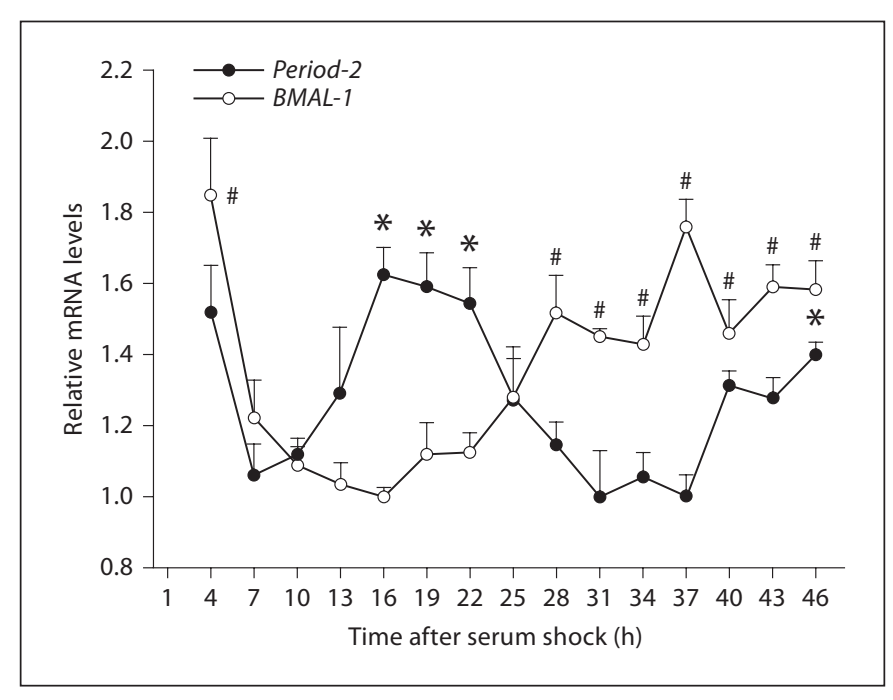

Fig. 1. Mouse Period-2 and $B M A L-1$ expression exhibit a daily pattern in GT1-7 cells. Fluctuations in mRNA levels after serum shock were quantified by real-time PCR and normalized to mouse $\beta$-actin mRNA. Average gene expression is shown as a percentage of the minimal expression during the day. Error bars represent standard errors $(\mathrm{n}=3)$. Mouse Period $-2\left(\mathrm{~F}_{14,44}=13.407, \mathrm{p}<0.001\right)$ and BMAL-1 $\left(\mathrm{F}_{14,44}=18.634, \mathrm{p}<0.001\right) \mathrm{mRNA}$ levels exhibit a $\sim 24$-hour pattern in anti-phase to each other. ${ }^{*}$ Significantly greater Period-2 expression than the lowest value over the course of the sampling period: $\mathrm{p}<0.05$. " Significantly greater $B M A L-1$ expression than the lowest value over the course of the sampling period: $\mathrm{p}<0.05$.

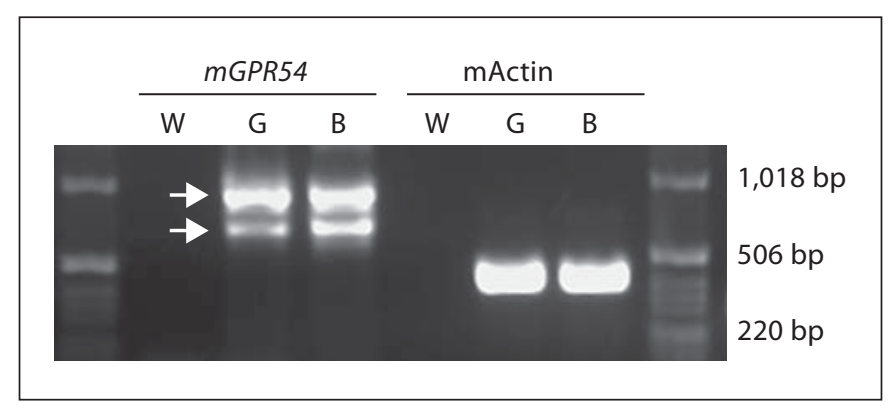

Fig. 2. GPR54 is expressed in GT1-7 cells. Mouse GPR54 ( $m$ GPR54) in mouse brain (B) and GT1-7 cells (G) was detected by RT-PCR. Water (W) was used as negative control and $\beta$-actin (mActin) was used as an internal control.

er kisspeptin stimulates GnRH release in GT1-7 cells, cells were treated for $45 \mathrm{~min}$ using a range of kisspeptin doses $(1 \mathrm{nM}$ to $10 \mu \mathrm{M})$, at $13 \mathrm{~h}$ following serum shock. Kisspeptin-mediated $\mathrm{GnRH}$ release was observed at doses ranging from 1 to $10 \mathrm{nM}(\mathrm{p}<0.05$ in each case, $\mathrm{n}=3$ /

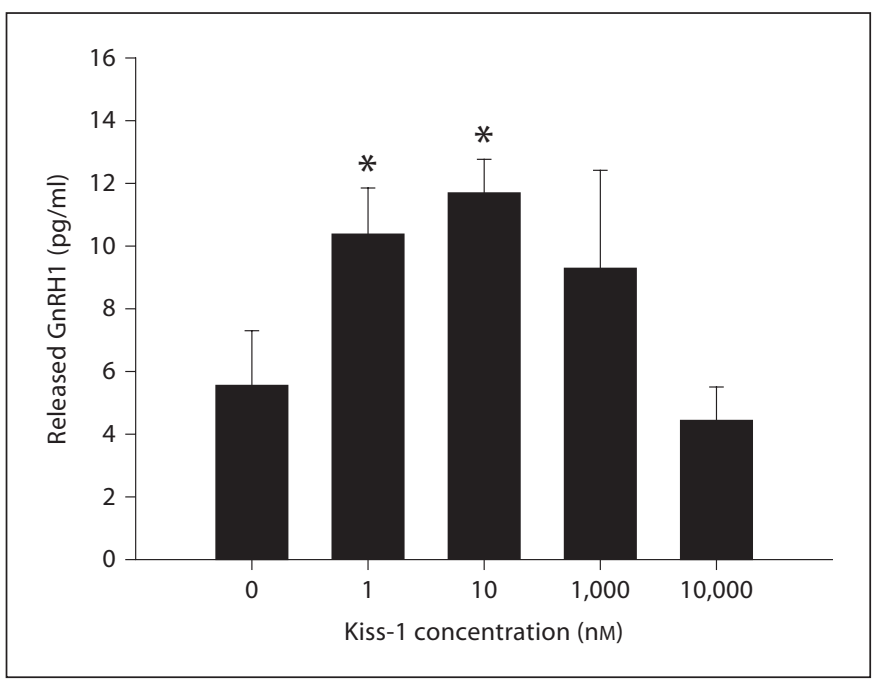

Fig. 3. Dose-dependent stimulation of $\mathrm{GnRH}$ release by kisspeptin treatment in GT1-7 cells. After $13 \mathrm{~h}$ of serum starving, GT1-7 cells were treated with kisspeptin (Kiss-1) for $45 \mathrm{~min}$. Error bars represent standard errors $(\mathrm{n}=3)$. Kisspeptin significantly ( $\left.{ }^{*} \mathrm{p}<0.05\right)$ increased GnRH release at 1 and $10 \mathrm{nM}$ concentrations with no increase seen after higher concentrations (e.g. $1 \mu \mathrm{M}$ and $10 \mu \mathrm{M})$ relative to PBS controls.

dose), but was abolished at higher doses ( 1 and $10 \mu \mathrm{M}$; $\mathrm{p}>0.05$ in each case; fig. 3 ). As a result, we selected a 5-nM dose of kisspeptin to explore the effects of this peptide on GnRH peptide and mRNA expression, while avoiding potential 'ceiling' or 'floor' effects.

\section{Temporal Sensitivity of GT1-7 Cells in Response to Kisspeptin and VIP}

Based on the dose response curve for kisspeptin (fig. 3) and previous reports characterizing the GT1-7 cell response to VIP [40], we chose a 5-nM concentration for kisspeptin and a 0.5-nM concentration for VIP to assess the daily rhythm in responsiveness to both peptides following serum shock. We first examined intracellular GnRH peptide content following kisspeptin treatment. GT1-7 cells showed a robust increase in GnRH peptide following both kisspeptin and VIP treatment $7 \mathrm{~h}$ after serum shock ( $\mathrm{p}<0.05$ in each case, $\mathrm{n}=4 /$ peptide), followed by a general insensitivity to this peptide 13 and $19 \mathrm{~h}$ after serum shock $(\mathrm{p}>0.05$ in each case, $\mathrm{n}=4 /$ time point/peptide; fig. 4). At $25 \mathrm{~h}$, cells exhibited a small increase in sensitivity to stimulation by kisspeptin and VIP ( $\mathrm{p}<0.05$ in both cases, $\mathrm{n}=4 /$ peptide) .

GnRH mRNA and GnRH peptide release were examined during a 46-hour period. In contrast to measures in 


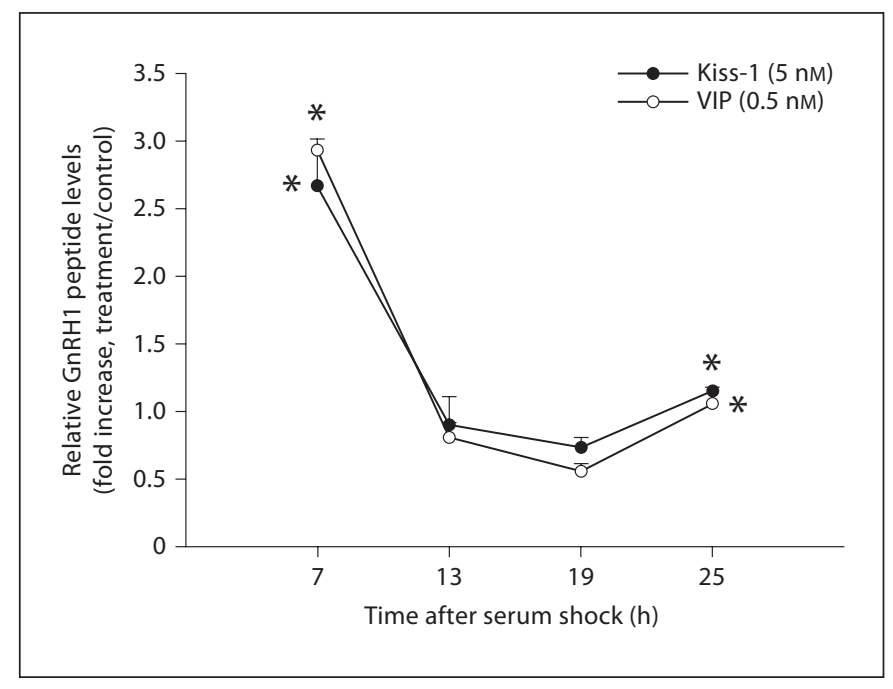

Fig. 4. GT1-7 cells exhibit daily changes in sensitivity to kisspeptin and VIP stimulation. Post-transcriptional regulation of GnRH in GT1-7 cells is responsive to kisspeptin or VIP treatment at various time points up to $25 \mathrm{~h}$ after serum shock. Data are presented as the fold increase above untreated samples for each time point. Error bars represent standard errors $(n=4)$. * Significantly greater than the lowest value over the course of the sampling period: $\mathrm{p}<0.05$. Kisspeptin and VIP treatments showed a similar stimulation pattern across the sampling period, with cellular GnRH peptide showing changes in expression level to the stimulation over the course of the sampling period.

peptide expression, GnRH mRNA transcripts were equally affected at all time points following kisspeptin and VIP treatment ( $\mathrm{p}>0.05$ in all cases, $\mathrm{n}=3 /$ time point/ peptide; fig. 5). In contrast, $\mathrm{GnRH}$ release in response to kisspeptin (fig. 6A) and VIP (fig. 6B; $\mathrm{p}<0.05, \mathrm{n}=3 /$ time point/peptide) was differentially affected by time of stimulation. Kisspeptin treatment resulted in an elevation of released $\mathrm{GnRH}$ at 28 and $46 \mathrm{~h}(\mathrm{p}<0.05$ in each case) with a marginally significant increase $4 \mathrm{~h}$ after serum shock. Elevation of GnRH release in response to VIP treatment was observed at 4,22 , and $46 \mathrm{~h}$ with maxima up to $\sim 7$-fold that of untreated controls $(p<0.05$ in each case).

\section{Discussion}

The present findings suggest that immortalized $\mathrm{GnRH}$ cells exhibit intrinsic daily changes in sensitivity to neurochemicals stimulating their activity (fig. 4, 6). Additionally, these studies have uncovered at least two alternatively spliced isoforms of GPR54 in GT1-7 cells (fig. 2),

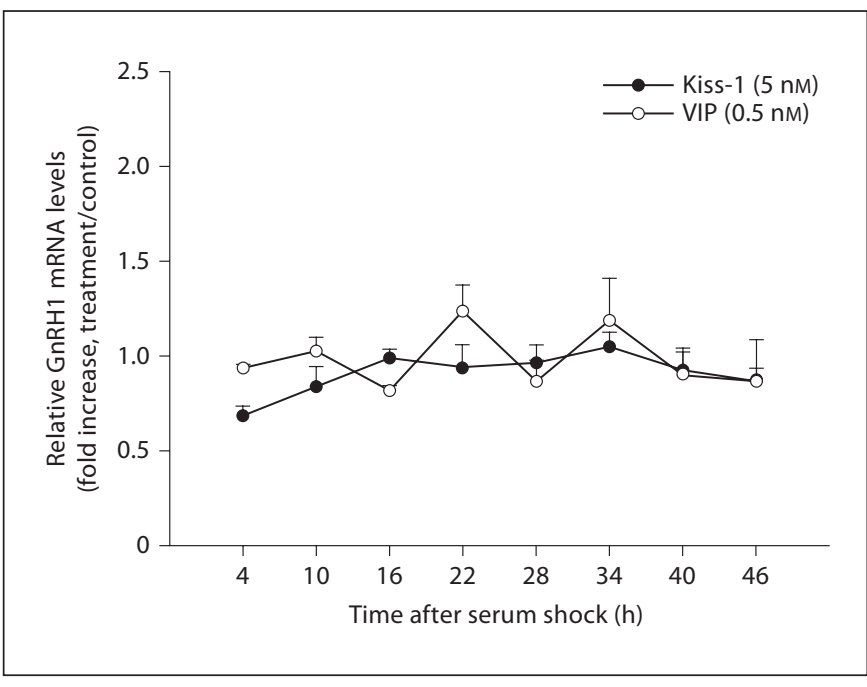

Fig. 5. GT1-7 cells do not show daily changes in GnRH mRNA following kisspeptin and VIP stimulation. GnRH mRNA levels were detected by real-time PCR after kisspeptin or VIP treatment at various time points up to $46 \mathrm{~h}$ after serum shock. Data are presented as the fold increase above untreated samples for each time point. Error bars represent standard errors $(n=3)$. No significant rhythm was detected for GnRH transcription following kisspeptin $\left(\mathrm{F}_{7,23}=0.962, \mathrm{p}=0.490\right)$ or $\operatorname{VIP}\left(\mathrm{F}_{7,23}=1.752, \mathrm{p}=0.167\right)$ treatments.

a finding further confirmed in mouse whole-brain cDNA. Other groups have recently reported one isoform of GPR54 in GT1-7 cells [63, 64]. In contrast to the present work, the primers used in these studies do not cover the alternative splicing region of the gene. Administration of kisspeptin promotes $\mathrm{GnRH}$ release in a dose-dependent manner with a saturable concentration in GT1-7 cells (fig. 3). Previous reports demonstrated dose-dependent effects of VIP stimulation on GnRH release in this same cell population [40], and we have replicated and extended these earlier findings, showing daily changes in sensitivity to this peptide. Previous studies in perifused GT1-7 cells suggested that rapid transcriptional and translational regulation is not involved in GnRH pulsatility by applying transcriptional and translational inhibitors to these cells [65]. In this study, we investigated GnRH production at the transcriptional level, translational level and secretion level. For both kisspeptin and VIP, no significant differences in GnRH mRNA were detected throughout the day (fig. 5), implying that rapid GnRH transcriptional regulation does not occur in response to peptide stimulation. In contrast, time-dependent responses to kisspeptin and VIP at the translational/posttranslational and secretory levels were observed. Togeth- 


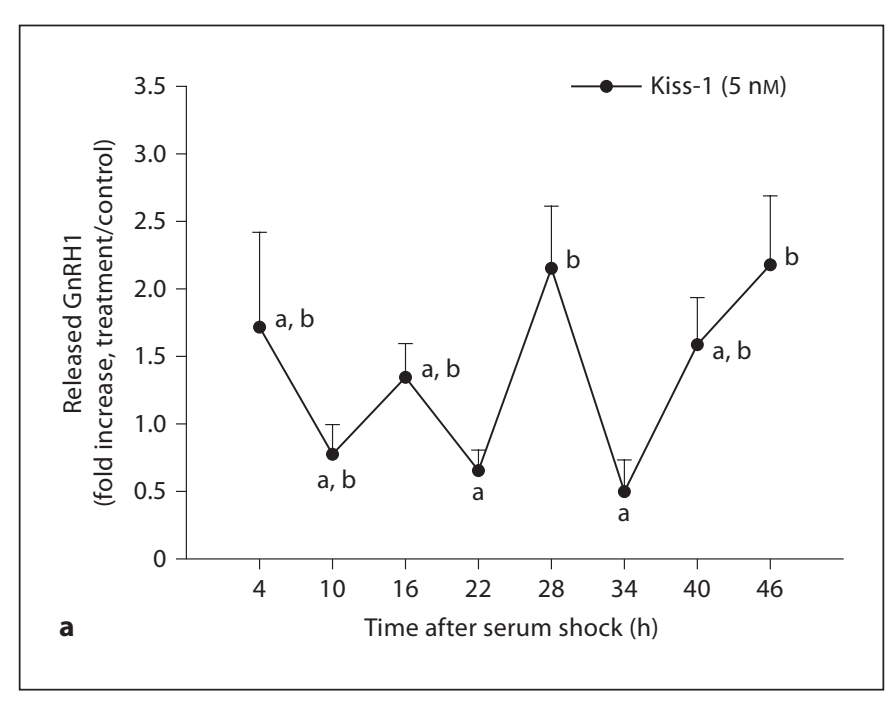

Fig. 6. GT1-7 cells show daily changes in GnRH release following kisspeptin (5 $\mathrm{nM})$ and VIP $(0.5 \mathrm{nM})$ stimulation. GnRH release in response to kisspeptin or VIP stimulation was monitored at various time points up to $46 \mathrm{~h}$ following serum shock. Data are presented as the fold increase above untreated samples for each time point. Error bars represent standard errors $(n=3)$. a Kisspeptin treatments initiated maximum $\mathrm{GnRH}$ release approximately ev-

er, these findings indicate that the GT1-7 cells, and perhaps the GnRH system in vivo, exhibit an endogenous time-dependent sensitivity to neurochemical stimulation. However, to confirm a rhythm in sensitivity to $\mathrm{GnRH}$ secretagogues, future investigations examining this system across several daily cycles are necessary.

The model system used in the present series of studies allows the investigation of the reproductive neuroendocrine axis uncoupled from the master pacemaker in the SCN. Recent studies suggest that the coordination of subordinate clocks is central for normal physiology [66-69]. As described previously, the peripheral time-keeping system is subordinate to the SCN and requires input from the master clock for its maintenance [18, 62]. Studies using food restriction indicate that peripheral oscillators can become uncoupled from central oscillators when hormonal signals conflict with SCN output $[70,71]$. Under normal circumstances, individual cellular clocks from a given system are synchronized to each other, but this synchrony is lost in peripheral clock cell populations in culture when removed from SCN input [18]. In vitro, Chappell et al. [58] found that clock genes in GT1-7 cells oscillate with a circadian period following serum shock, and pulsatile $\mathrm{GnRH}$ secretion appears to be regulated by these oscillations. The Period-2 and BMAL-1 mRNA patterns in the present studies are consistent with this origi-

Daily Changes in GT1-7 Cell Sensitivity

to GnRH Secretagogues

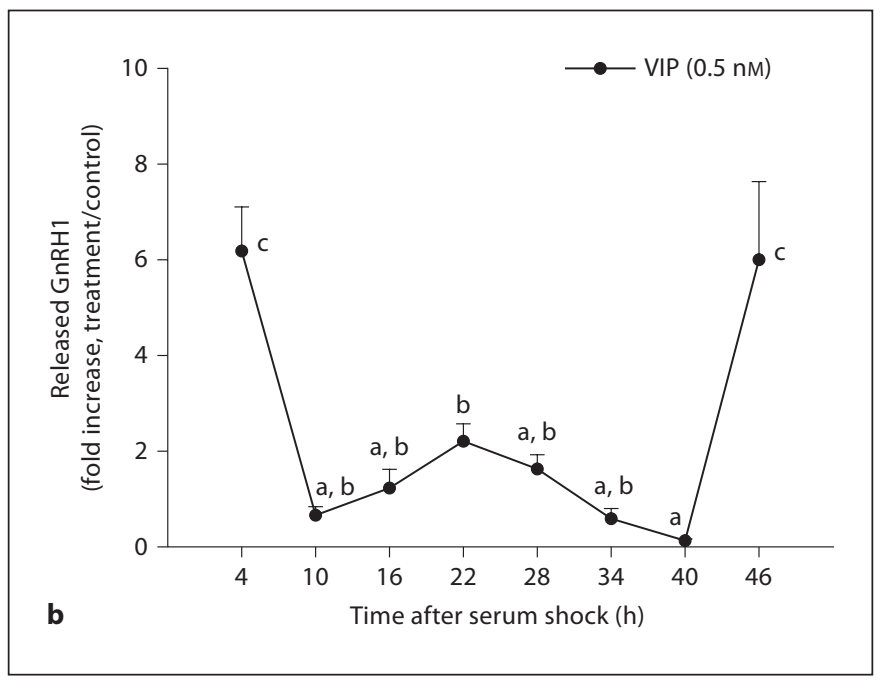

ery $20-26 \mathrm{~h}\left(\mathrm{~F}_{7,23}=2.707, \mathrm{p}=0.047\right)$. b Similarly, VIP treatments initiated maximum $\mathrm{GnRH}$ release approximately every $22-24 \mathrm{~h}$ $\left(\mathrm{F}_{7,23}=11.675, \mathrm{p}<0.001\right)$. A post hoc test (Waller-Duncan test, type I/type II error ratio $=100$, significance level $=0.05$ ) was used to compare the means of all time points. Time points not sharing a letter in common are significantly different: $\mathrm{p}<0.05$.

nal report. Additional evidence for a circadian mechanism in GT1-7 cells comes from studies in which melatonin treatment leads to increases in cellular melatonin receptor expression, but only at distinct circadian periods [72]. Likewise, the ability of melatonin to inhibit GnRH secretion varies with a circadian period when examined over $48 \mathrm{~h}$ in this immortalized population [73]. Our results demonstrate a daily change in sensitivity of GT1-7 cells to kisspeptin and VIP treatment, suggesting the possibility that the intrinsic circadian time-keeping apparatus in extra-SCN cells provides a mechanism for altering local responsiveness to upstream neuromodulators. Future studies using molecular approaches to disrupt the cellular clock are necessary to determine whether these daily changes in sensitivity are mediated by local oscillators in this cell population.

The SCN neuropeptide VIP is a key regulator of the ovulatory cycle in rodents. Administration of VIP antiserum [34] or antisense oligodeoxynucleotides [42] alters the time course and reduces the magnitude of the LH and prolactin surges on the afternoon of proestrus. The present findings indicate that the effects of VIP on the GnRH system depend on the timing of administration. Similar findings have been reported for vasopressin in vivo; vasopressin administration can stimulate the LH surge [74, 75], and its effects have been shown to depend on timing 
of administration [75]. Whether vasopressin acts directly on GnRH cells or via an intermediate system remains unclear. One recent study has demonstrated the innervation of AVPV kisspeptin neurons by vasopressin immunoreactive fibers [76], suggesting that this kisspeptin pathway may provide an indirect route between the SCN and the HPG axis [47, 53, 55, 77-79]. A vasopressinergic pathway from the SCN to AVPV kisspeptin cells would allow circadian control of this potent stimulator of reproductive axis function.

Several lines of evidence support a role for AVPV kisspeptin as an integration point for circadian and steroidal signals necessary for initiation of the LH surge. First, a large proportion of kisspeptin cells express estrogen receptor- $\alpha$, the receptor subtype important for the positive feedback effects of this sex steroid during the surge [45, $80-82]$. Additionally, kisspeptin mRNA in the AVPV is increased in a timed manner, with maximum expression on the afternoon of proestrus $[50,83]$. Importantly, this expression pattern is dependent on the presence of high concentrations of estrogen [50, 83]. Likewise, kisspeptin neurons exhibit an increase in FOS expression concomitant with the LH surge [50]. Infusion of an anti-kisspeptin antiserum into the pre-optic area of rats blocks the $\mathrm{LH}$ surge [83]. In the ewe, kisspeptin can alter the timing of the LH surge and stimulate ovulation in anestrous animals [84]. In anestrous female Siberian hamsters housed in short days, kisspeptin treatment does not lead to an increase in $\mathrm{LH}$, indicating an alteration in GnRH cell sensitivity to this peptide as a potential additional mechanism of ovulatory inhibition during winter [85].

In rodents whose ovulatory cycle is tied to the circadian system, this mechanism ensures that ovulation is coordinated with female sexual motivation and the time of day during which males are seeking a mate. Additionally, estrogen-dependence of this timing mechanism safeguards against the preovulatory LH surge occurring before the oocyte is fully mature. Together with these previous findings, the present data showing daily changes in GT1-7 cell sensitivity to kisspeptin stimulation suggest that local time-dependent sensitivity of GnRH neurons might be an important additional component of the SCN-HPG and SCN-AVPV-HPG circuits required for proper endocrine timing. Because the present study did not specifically investigate daily changes in the ability of GT1-7 cells to produce GnRH, it is possible that such modifications contribute to observed patterns of expression. Future studies in which GT1-7 cells are stimulated with a neurochemical that consistently causes GnRH release are necessary to examine this possibility.

The present results suggest a mechanism of HPG axis control in which the gating of stimulated $\mathrm{GnRH}$ secretion is coordinated locally within the GnRH neuronal network. Whether or not circadian clock genes participate in this rhythm in sensitivity represents an exciting avenue for further investigation. As indicated previously, core circadian clock genes are expressed in neurosecretory cells [87], the pituitary gland [21, 22], and other peripheral endocrine glands $[23,24,88]$, suggesting that this mechanism of local temporal control may operate at multiple levels of the HPG axis providing opportunity to explore this novel regulatory system.

\section{Acknowledgments}

The anti-mouse $\beta$-actin antibody developed by Dr. Jim JungChing Lin was obtained from the Developmental Studies Hybridoma Bank developed under the auspices of the NICHD and maintained by the University of Iowa, Department of Biological Sciences, Iowa City, IA 52242. We thank Dr. P.L. Mellon and Dr. R.I. Weiner for providing the GT1-7 cell line. We also thank Dr. Daniela Kaufer for the use of her cell culture facility. We thank Dr. Ilia Karatsoreos for helpful comments on an earlier version of the manuscript. This research was supported by NIH grant HD050470 (L.J.K.).

\section{References}

1 Kriegsfeld LJ, Silver R: The regulation of neuroendocrine function: timing is everything. Horm Behav 2006;49:557-574.

$\checkmark 2$ Moore RY, Eichler VB: Loss of a circadian adrenal corticosterone rhythm following suprachiasmatic lesions in the rat. Brain Res 1972;42:201-206.

-3 Stephan FK, Zucker I: Circadian rhythms in drinking behavior and locomotor activity of rats are eliminated by hypothalamic lesions. Proc Natl Acad Sci USA 1972;69:1583-1586.
4 Reppert SM, Weaver DR: Coordination of circadian timing in mammals. Nature 2002; 418:935-941.

-5 Bradbury MJ, Akana SF, Cascio CS, Levin N, Jacobson L, Dallman MF: Regulation of basal ACTH secretion by corticosterone is mediated by both type I (MR) and type II (GR) receptors in rat brain. J Steroid Biochem Mol Biol 1991;40:133-142.
6 Bradbury MJ, Cascio CS, Scribner KA, Dallman MF: Stress-induced adrenocorticotropin secretion: diurnal responses and decreases during stress in the evening are not dependent on corticosterone. Endocrinology $1991 ; 128: 680-688$.

7 Buijs RM, Wortel J, Van Heerikhuize JJ, Kalsbeek A: Novel environment induced inhibition of corticosterone secretion: physiological evidence for a suprachiasmatic nucleus mediated neuronal hypothalamo-adrenal cortex pathway. Brain Res 1997;758:229-236. 
${ }_{8}$ Perreau-Lenz S, Kalsbeek A, Garidou ML, Wortel J, van der Vliet J, van Heijningen C, Simonneaux V, Pevet P, Buijs RM: Suprachiasmatic control of melatonin synthesis in rats: inhibitory and stimulatory mechanisms. Eur J Neurosci 2003;17:221-228.

-9 Jasper MS, Engeland WC: Splanchnic neural activity modulates ultradian and circadian rhythms in adrenocortical secretion in awake rats. Neuroendocrinology 1994;59: 97-109.

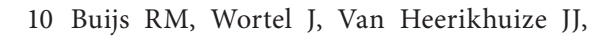
Feenstra MG, Ter Horst GJ, Romijn HJ, Kalsbeek A: Anatomical and functional demonstration of a multisynaptic suprachiasmatic nucleus adrenal (cortex) pathway. Eur J Neurosci 1999;11:1535-1544.

-11 Buijs RM, la Fleur SE, Wortel J, Van Heyningen C, Zuiddam L, Mettenleiter TC, Kalsbeek A, Nagai K, Niijima A: The suprachiasmatic nucleus balances sympathetic and parasympathetic output to peripheral organs through separate preautonomic neurons. J Comp Neurol 2003;464:36-48.

12 Shibata S: Neural regulation of the hepatic circadian rhythm. Anat Rec 2004;280:901909.

-13 Terazono H, Mutoh T, Yamaguchi S, Kobayashi M, Akiyama M, Udo R, Ohdo S, Okamura H, Shibata S: Adrenergic regulation of clock gene expression in mouse liver. Proc Natl Acad Sci USA 2003;100:67956800.

14 Liu D, Peddada SD, Li L, Weinberg CR: Phase analysis of circadian-related genes in two tissues. BMC Bioinformatics 2006;7:87.

- 15 Nakahata Y, Grimaldi B, Sahar S, Hirayama J, Sassone-Corsi P: Signaling to the circadian clock: Plasticity by chromatin remodeling. Curr Opin Cell Biol 2007;19:230-237.

16 Kohsaka A, Bass J: A sense of time: how molecular clocks organize metabolism. Trends Endocrinol Metab 2007;18:4-11.

$\checkmark 17$ Liu AC, Welsh DK, Ko CH, Tran HG, Zhang EE, Priest AA, Buhr ED, Singer O, Meeker K, Verma IM, Doyle FJ 3rd, Takahashi JS, Kay SA: Intercellular coupling confers robustness against mutations in the SCN circadian clock network. Cell 2007;129:605-616.

- 18 Welsh DK, Yoo SH, Liu AC, Takahashi JS, Kay SA: Bioluminescence imaging of individual fibroblasts reveals persistent, independently phased circadian rhythms of clock gene expression. Curr Biol 2004;14:2289-2295.

$\checkmark 19$ Kriegsfeld LJ, Silver R, Gore AC, Crews D: Vasoactive intestinal polypeptide contacts on gonadotropin-releasing hormone neurones increase following puberty in female rats. J Neuroendocrinol 2002;14:685-690.

20 Olcese J, Domagalski R, Bednorz A, Weaver DR, Urbanski HF, Reuss S, Middendorff R: Expression and regulation of mperl in immortalized GnRH neurons. Neuroreport 2003;14:613-618.
21 Shieh KR: Distribution of the rhythm-related genes rPERIOD1, rPERIOD2, and rCLOCK, in the rat brain. Neuroscience 2003;118:831-843.

22 von Gall C, Garabette ML, Kell CA, Frenzel S, Dehghani F, Schumm-Draeger PM, Weaver DR, Korf HW, Hastings MH, Stehle JH: Rhythmic gene expression in pituitary depends on heterologous sensitization by the neurohormone melatonin. Nature Neurosci 2002;5:234-238.

23 Bittman EL, Doherty L, Huang L, Paroskie A: Period gene expression in mouse endocrine tissues. Am J Physiol 2003;285:R561R569.

24 Zylka MJ, Shearman LP, Weaver DR, Reppert SM: Three period homologs in mammals: differential light responses in the suprachiasmatic circadian clock and oscillating transcripts outside of brain. Neuron 1998;20:1103-1110.

25 Buijs RM, Chun SJ, Niijima A, Romijn HJ, Nagai K: Parasympathetic and sympathetic control of the pancreas: a role for the suprachiasmatic nucleus and other hypothalamic centers that are involved in the regulation of food intake. J Comp Neurol 2001;431:405423.

26 Gerendai I, Toth IE, Boldogkoi Z, Medveczky I, Halasz B: CNS structures presumably involved in vagal control of ovarian function. J Auton Nerv Syst 2000;80:40-45.

27 Kreier F, Fliers E, Voshol PJ, Van Eden CG, Havekes LM, Kalsbeek A, Van Heijningen CL, Sluiter AA, Mettenleiter TC, Romijn JA, Sauerwein HP, Buijs RM: Selective parasympathetic innervation of subcutaneous and intra-abdominal fat - functional implications. J Clin Invest 2002;110:1243-1250.

28 Strack AM, Sawyer WB, Platt KB, Loewy $\mathrm{AD}$ : CNS cell groups regulating the sympathetic outflow to adrenal gland as revealed by transneuronal cell body labeling with pseudorabies virus. Brain Res 1989;491:274296.

29 Bronson FH (ed): Mammalian Reproductive Biology. Chicago, University of Chicago Press, 1990.

30 Herbison AE: Physiology of the GnRH neuronal networks; in Knobil E, Neill JD (eds): Physiology of Reproduction, ed 3. San Diego, Elsevier, 2005, pp 1415-1482.

31 Levine JE: Gonadotropin-releasing hormone $(\mathrm{GnRH})$; in Herny H, Normona A (eds): Encyclopedia of Hormones. San Diego, Academic Press, 2003, pp 157-165.

32 Van der Beek EM, Horvath TL, Wiegant VM, Van den Hurk R, Buijs RM: Evidence for a direct neuronal pathway from the suprachiasmatic nucleus to the gonadotropin-releasing hormone system: combined tracing and light and electron microscopic immunocytochemical studies. J Comp Neurol 1997;384: 569-579.
33 van der Beek EM, van Oudheusden HJ, Buijs RM, van der Donk HA, van den Hurk R, Wiegant VM: Preferential induction of c-fos immunoreactivity in vasoactive intestinal polypeptide-innervated gonadotropin-releasing hormone neurons during a steroidinduced luteinizing hormone surge in the female rat. Endocrinology 1994;134:26362644.

34 van der Beek EM, Swarts HJ, Wiegant VM: Central administration of antiserum to vasoactive intestinal peptide delays and reduces luteinizing hormone and prolactin surges in ovariectomized, estrogen-treated rats. Neuroendocrinology 1999;69:227-237.

35 Legan SJ, Karsch FJ: A daily signal for the LH surge in the rat. Endocrinology 1975;96:5762.

36 Gray GD, Soderstein P, Tallentire D, Davidson JM: Effects of lesions in various structures of the suprachiasmatic-preoptic region on LH regulation and sexual behavior in female rats. Neuroendocrinology 1978;25: 174-191.

37 Nunez AA, Stephan FK: The effects of hypothalamic knife cuts on drinking rhythms and the estrus cycle of the rat. Behav Biol 1977;20:224-234.

38 van der Beek EM, Wiegant VM, van der Donk HA, van den Hurk R, Buijs RM: Lesions of the suprachiasmatic nucleus indicate the presence of a direct vasoactive intestinal polypeptide-containing projection to gonadotrophin-releasing hormone neurons in the female rat. J Neuroendocrinol 1993;5: 137-144.

39 Smith MJ, Jiennes L, Wise PM: Localization of the VIP2 receptor protein on GnRH neurons in the female rat. Endocrinology 2000; 141:4317-4320.

40 Olcese J, McArdle CA, Middendorff R, Greenland K: Pituitary adenylate cyclaseactivating peptide and vasoactive intestinal peptide receptor expression in immortalized LHRH neurons. J Neuroendocrinol 1997;9: 937-943

41 Ohtsuka S, Miyake A, Nishizaki T, Tasaka K, Tanizawa O: Vasoactive intestinal peptide stimulates gonadotropin-releasing hormone release from rat hypothalamus in vitro. Acta Endocrinol 1988;117:399-402.

42 Harney JP, Scarbrough K, Rosewell KL, Wise PM: In vivo antisense antagonism of vasoactive intestinal peptide in the suprachiasmatic nuclei causes aging-like changes in the estradiol-induced luteinizing hormone and prolactin surges. Endocrinology 1996;137: 3696-3701.

43 Kimura F, Mitsugi N, Arita J, Akema T, Yoshida K: Effects of preoptic injections of gastrin, cholecystokinin, secretin, vasoactive intestinal peptide and phi on the secretion of luteinizing hormone and prolactin in ovariectomized estrogen-primed rats. Brain Res 1987;410:315-322. 
-44 Kinoshita M, Tsukamura H, Adachi S, Matsui $\mathrm{H}$, Uenoyama $\mathrm{Y}$, Iwata $\mathrm{K}$, Yamada S, Inoue K, Ohtaki T, Matsumoto H, Maeda K: Involvement of central metastin in the regulation of preovulatory luteinizing hormone surge and estrous cyclicity in female rats. Endocrinology 2005; 146:4431-4436.

-45 Wintermantel TM, Campbell RE, Porteous R, Bock D, Grone HJ, Todman MG, Korach KS, Greiner E, Perez CA, Schutz G, Herbison AE: Definition of estrogen receptor pathway critical for estrogen positive feedback to gonadotropin-releasing hormone neurons and fertility. Neuron 2006;52:271-280.

-46 Le WW, Attardi B, Berghorn KA, Blaustein J, Hoffman GE: Progesterone blockade of a luteinizing hormone surge blocks luteinizing hormone-releasing hormone fos activation and activation of its preoptic area afferents. Brain Res 1997;778:272-280.

-47 Kriegsfeld LJ, Leak RK, Yackulic CB, LeSauter J, Silver R: Organization of suprachiasmatic nucleus projections in Syrian hamsters (Mesocricetus auratus): an anterograde and retrograde analysis. J Comp Neurol 2004; 468:361-379.

48 Levine JE: New concepts of the neuroendocrine regulation of gonadotropin surges in rats. Biology Reprod 1997;56:293-302.

$\checkmark 49$ Kotani M, Detheux M, Vandenbogaerde A, Communi D, Vanderwinden JM, Le Poul E, Brezillon S, Tyldesley R, Suarez-Huerta N, Vandeput F, Blanpain C, Schiffmann SN, Vassart G, Parmentier M: The metastasis suppressor gene KiSS-1 encodes kisspeptins, the natural ligands of the orphan $G$ proteincoupled receptor GPR54. J Biol Chem 2001; 276:34631-34636.

50 Smith JT, Popa SM, Clifton DK, Hoffman GE, Steiner RA: Kiss1 neurons in the forebrain as central processors for generating the preovulatory luteinizing hormone surge. J Neurosci 2006;26:6687-6694.

-51 Shahab M, Mastronardi C, Seminara SB, Crowley WF, Ojeda SR, Plant TM: Increased hypothalamic GPR54 signaling: a potential mechanism for initiation of puberty in primates. Proc Natl Acad Sci USA 2005; 102: 2129-2134.

-52 Ohtaki T, Shintani Y, Honda S, Matsumoto H, Hori A, Kanehashi K, Terao Y, Kumano S, Takatsu Y, Masuda Y, Ishibashi Y, Watanabe T, Asada M, Yamada T, Suenaga M, Kitada C, Usuki S, Kurokawa T, Onda H, Nishimura O, Fujino M: Metastasis suppressor gene KiSS-1 encodes peptide ligand of a G-protein-coupled receptor. Nature 2001;411:613-617.

53 Han SK, Gottsch ML, Lee KJ, Popa SM, Smith JT, Jakawich SK, Clifton DK, Steiner RA, Herbison AE: Activation of gonadotropin-releasing hormone neurons by kisspeptin as a neuroendocrine switch for the onset of puberty. J Neurosci 2005;25:1134911356.
54 Irwig MS, Fraley GS, Smith JT, Acohido BV, Popa SM, Cunningham MJ, Gottsch ML, Clifton DK, Steiner RA: Kisspeptin activation of gonadotropin releasing hormone neurons and regulation of KiSS-1 mRNA in the male rat. Neuroendocrinology 2004;80: 264-272.

55 Messager S, Chatzidaki EE, Ma D, Hendrick AG, Zahn D, Dixon J, Thresher RR, Malinge I, Lomet $\mathrm{D}$, Carlton $\mathrm{MB}$, Colledge $\mathrm{WH}$, Caraty A, Aparicio SA: Kisspeptin directly stimulates gonadotropin-releasing hormone release via $G$ protein-coupled receptor 54 . Proc Natl Acad Sci USA 2005; 102:17611766.

56 Gottsch ML, Cunningham MJ, Smith JT, Popa SM, Acohido BV, Crowley WF, Seminara S, Clifton DK, Steiner RA: A role for kisspeptins in the regulation of gonadotropin secretion in the mouse. Endocrinology 2004; 145:4073-4077.

57 Balsalobre A, Damiola F, Schibler U: A serum shock induces circadian gene expression in mammalian tissue culture cells. Cell 1998;93:929-937.

58 Chappell PE, White RS, Mellon PL: Circadian gene expression regulates pulsatile gonadotropin-releasing hormone $(\mathrm{GnRH})$ secretory patterns in the hypothalamic GnRH-secreting GT1-7 cell line. J Neurosci 2003;23:11202-11213.

59 Zhao S, Fernald RD: Comprehensive algorithm for quantitative real-time polymerase chain reaction. J Comput Biol 2005;12:10471064.

60 Reppert SM, Weaver DR: Molecular analysis of mammalian circadian rhythms. Annu Rev Physiol 2001;63:647-676.

61 Ripperger JA, Schibler U: Circadian regulation of gene expression in animals. Curr Opin Cell Biol 2001;13:357-362.

62 Schibler U, Ripperger J, Brown SA: Peripheral circadian oscillators in mammals: time and food. J Biol Rhythms 2003;18:250-260.

63 Jacobi JS, Martin C, Nava G, Jeziorski MC, Clapp C, Martinez de la Escalera G: 17-Betaestradiol directly regulates the expression of adrenergic receptors and kisspeptin/GPR54 system in GT1-7 GnRH neurons. Neuroendocrinology 2007;86:260-269.

64 Quaynor S, Hu L, Leung PK, Feng H, Mores N, Krsmanovic LZ, Catt KJ: Expression of a functional G protein-coupled receptor 54kisspeptin autoregulatory system in hypothalamic gonadotropin-releasing hormone neurons. Mol Endocrinol 2007;21:30623070.

65 Pitts GR, Nunemaker CS, Moenter SM: Cycles of transcription and translation do not comprise the gonadotropin-releasing hormone pulse generator in GT1 cells. Endocrinology 2001;142:1858-1864.

66 Buijs RM, Scheer FA, Kreier F, Yi C, Bos N, Goncharuk VD, Kalsbeek A: Organization of circadian functions: interaction with the body. Prog Brain Res 2006;153:341-360.
67 Davidson AJ, London B, Block GD, Menaker M: Cardiovascular tissues contain independent circadian clocks. Clin Exp Hypertens 2005;27:307-311.

68 Levi F, Schibler U: Circadian rhythms: mechanisms and therapeutic implications. Annu Rev Pharmacol Toxicol 2007;47:593-628.

69 Yamazaki S, Numano R, Abe M, Hida A, Takahashi R, Ueda M, Block GD, Sakaki Y, Menaker M, Tei H: Resetting central and peripheral circadian oscillators in transgenic rats. Science 2000;288:682-685.

70 Damiola F, Le Minh N, Preitner N, Kornmann B, Fleury-Olela F, Schibler U: Restricted feeding uncouples circadian oscillators in peripheral tissues from the central pacemaker in the suprachiasmatic nucleus. Genes Dev 2000;14:2950-2961.

71 Hirao J, Arakawa S, Watanabe K, Ito K, Furukawa $\mathrm{T}$ : Effects of restricted feeding on daily fluctuations of hepatic functions including p450 monooxygenase activities in rats. J Biol Chem 2006;281:3165-3171.

-72 Gillespie JM, Chan BP, Roy D, Cai F, Belsham DD: Expression of circadian rhythm genes in gonadotropin-releasing hormone-secreting GT1-7 neurons. Endocrinology 2003;144: 5285-5292.

73 Roy D, Angelini NL, Fujieda H, Brown GM, Belsham DD: Cyclical regulation of $\mathrm{GnRH}$ gene expression in GT1-7 GnRH-secreting neurons by melatonin. Endocrinology 2001; 142:4711-4720.

74 Miller BH, Olson SL, Levine JE, Turek FW, Horton TH, Takahashi JS: Vasopressin regulation of the proestrous luteinizing hormone surge in wild-type and clock mutant mice. Biol Reprod 2006;75:778-784.

75 Palm IF, van der Beek EM, Wiegant VM, Buijs RM, Kalsbeek A: The stimulatory effect of vasopressin on the luteinizing hormone surge in ovariectomized, estradioltreated rats is time-dependent. Brain Res 2001;901:109-116.

76 Kallo I, Vida B, Kalamatianos T, Hrabovszky E, Caraty A, Liposits Z, Coen CW: Innervation of kisspeptin neurons by vasopressinand VIP-immunoreactive fibers in the anteroventral periventricular and preoptic periventricular nuclei of the mouse. Poster Neuroscience Meeting, San Diego, 2007.

77 Leak RK, Moore RY: Topographic organization of suprachiasmatic nucleus projection neurons. J Comp Neurol 2001;433:312-334.

78 Hahn JD, Coen CW: Comparative study of the sources of neuronal projections to the site of gonadotrophin-releasing hormone perikarya and to the anteroventral periventricular nucleus in female rats. J Comp Neurol 2006;494:190-214.

79 Greives TJ, Mason AO, Scotti MA, Levine J, Ketterson ED, Kriegsfeld LJ, Demas GE: Environmental control of kisspeptin: implications for seasonal reproduction. Endocrinology 2007;148:1158-1166. 
80 Franceschini I, Lomet D, Cateau M, Delsol G, Tillet Y, Caraty A: Kisspeptin immunoreactive cells of the ovine preoptic area and arcuate nucleus co-express estrogen receptor alpha. Neurosci Lett 2006;401:225-230.

81 Herbison AE: Estrogen positive feedback to gonadotropin-releasing hormone $(\mathrm{GnRH})$ neurons in the rodent: the case for the rostral periventricular area of the third ventricle (RP3V). Brain Res Rev 2008;57:277-287.

82 Smith JT: Kisspeptin signalling in the brain: steroid regulation in the rodent and ewe. Brain Res Rev 2008;57:288-298.

$\checkmark 3$ Adachi S, Yamada S, Takatsu Y, Matsui H, Kinoshita M, Takase K, Sugiura H, Ohtaki T, Matsumoto $\mathrm{H}$, Uenoyama $\mathrm{Y}$, Tsukamura $\mathrm{H}$, Inoue $\mathrm{K}$, Maeda K: Involvement of anteroventral periventricular metastin/kisspeptin neurons in estrogen positive feedback action on luteinizing hormone release in female rats. J Reprod Dev 2007;53:367-378.
84 Caraty A, Smith JT, Lomet D, Ben Said S, Morrissey A, Cognie J, Doughton B, Baril G, Briant C, Clarke IJ: Kisspeptin synchronizes preovulatory surges in cyclical ewes and causes ovulation in seasonally acyclic ewes. Endocrinology 2007; 148:5258-5267.

85 Mason AO, Greives TJ, Scotti MA, Levine J, Frommeyer S, Ketterson ED, Demas GE, Kriegsfeld LJ: Suppression of kisspeptin expression and gonadotropic axis sensitivity following exposure to inhibitory day lengths in female Siberian hamsters. Horm Behav 2007;52:492-498.
6 Dhillo WS, Chaudhri OB, Thompson EL, Murphy KG, Patterson M, Ramachandran R, Nijher GK, Amber V, Kokkinos A, Donaldson M, Ghatei MA, Bloom SR: Kisspeptin-54 stimulates gonadotropin release most potently during the preovulatory phase of the menstrual cycle in women. J Clin Endocrinol Metab 2007;92:3958-3966.

87 Kriegsfeld LJ, Korets R, Silver R: Expression of the circadian clock gene Period 1 in neuroendocrine cells: an investigation using mice with a Per1::GFP transgene. Eur J Neurosci 2003;17:212-220.

- 88 Morse D, Cermakian N, Brancorsini S, Parvinen M, Sassone-Corsi P: No circadian rhythms in testis: Period 1 expression is clock independent and developmentally regulated in the mouse. Mol Endocrinol 2003;17:141151. 